\title{
Are There Techno-Scientific Projects In Mexico?
}

\author{
Vega-González Luis Roberto \\ Coordinación de Vinculación y Gestión Tecnológica \\ Herrera-Becerra Alberto Arturo \\ Grupo de Modelado y Simulación de Procesos
}

\begin{abstract}
The techno-scientific projects emerged during the 40's decade, and were consolidated in the United States of America pending the last decades of last century. This work's objective is to provide elements to understand how the techno-science systems of the developed countries function, to later visualize if there are similar projects in Mexico. The methodology used was the documents revision and a brief historical analysis of science, technology and engineering evolution to understand the essence of the disciplines that provided knowledge for the emergence of the techno-science. Furthermore, the relationship among science, technology, society and the techno-scientific projects is discussed from an axiological perspective. The results are that techno-science is not just the conjunction of the science and technology words, but a deeper issue that has to do with the action and the way in which big projects of research, development and innovation (R\&D+i) should be performed. These projects must have national scope and high social impact. The conclusion is that while it is true that the techno-scientific projects are well consolidated in the United States of America and in some developed countries, this does not occur in developing countries and therefore the incipient techno-scientific work teams face serious difficulties to develop innovation projects within the Mexican science and technology system in the different productive and service sectors of the economy.
\end{abstract}

Key Words: techno-science projects, engineering, science, technology, innovation, Mexico.

\section{INTRODUCTION}

At the beginning of the second decade of the XXI Century, at various academic circles in developing countries it has spread a recurring use of the techno-sciences term.

In some cases it seems that the techno-science term is just the conjunction of both terms techniques and sciences, nevertheless, heretofore it is well known that techno-science has to do with the innovation process. According to Rosenberg (2010, pp. vii), a serious study of the innovation processes and its derivatives has to be historically approached.

For that reason the methodology proposed to understand how the techno-scientific system works outside developed countries, begins with the study of the historical evolution of the precedent knowledge bodies and of the features of the techno-science, both emergent and consolidated. 
With these elements it is possible to visualize that the techno-sciences are not just a knowledge type by themselves, but a special social organizational way to produce new and useful knowledge through the development of projects of great scope and high social impact.

Immediately, this work is centred in the comprehension of the relevant characteristics of the techno-scientific projects and its role in modern society to finally review what is happening in this area across the country.

\section{Brief Overview of the Techniques, Technology and Engineering}

Historical records show that the word technology was present in early modern English language of the XVII century and so the first engineering schools appeared in Europe at the end of XVIII century.

The first to begin operations were the National School of Bridges and Civil Engineering in France, 1747. Then the Academy of Mines in Freiberg, Germany in 1765; the Artillery Academy in Segovia, Spain, 1764; and the Real Academy of Fortificação, Artilharia e Desenho in Lisbon, Portugal, 1790; while the first schools of engineering in Latin America were the Real Seminario de Minas in Mexico, 1792, created by Carlos IV of Spain (Lucena, 2007), and the Real Academy of Artilharia, Fortificação e Desenho in Rio de Janeiro, Brazil, 1792.

The work of the engineers has been always related with the use of the techniques and the technology for the operation and maintenance of the industrial production platforms, but what are the differences among techniques, technology and engineering?

Analysing the history of the terms, Schatzberg (2006), explains that at the end of the XIX century the technique word in England, France and Germany was referred to the methods and procedures of material culture, especially in engineering and industry while the technology word had to do with the description, principles or teaching and study of the practical arts and its principles; that is, in its first epoch the word technology was referred to the study field not to the study object. In those times, the artisan that worked in the great transformation industries like the textile industry were associated with the term engineer, word that until then was only used for the operators of military machinery like the catapults or cannons.

The word engineer comes from the Latin word ingenium, or person that uses cleverness cunningly and invents. By definition, the technique word is related to the technikos, a Greek word, and it refers to the art, artisanal capacity, skill, practical knowledge and the use of the language relative to mechanical and scientific themes. The technique and engineer terms have always been closely related.

It was until early XX century that the modern technology term also included the machining processes and that its importance was acknowledged in the global economy and the relationship of the scientific knowledge with the technology for useful purposes (Veblen, 1906; cited by Schatzberg op. Cit., page 503). Today the technology term includes both the practice and the study of the arts, the methods and the industrial procedures.

\section{Then, the technology has a close relationship with engineering, for Dillon $(2008, \mathbf{p p . 1 4})$}

The results of the engineering efforts are structures, processes or physical devices. Moreover, Leo Marx (2010) mentions that mechanical arts innovations have probably been part of the driving forces of the human history. Therefore, the domain of engineering and technology means human progress because the advance of the mechanical arts has been present throughout all human events; however, according to Antoine Picon (2004) the relationships 
between engineering history and society history still represent an open theme which is the object of a permanent research.

It is also important to say that some authors stress the importance of the contribution of the engineers not only in physics and mathematics but also in the emergence and development of administration and modern economy. (Chandler, 1977; Vérin, 1982; Porter, 1995; cited by Picon, Op. Cit.).

In their report, Marjoram y Zhong mentioned that the engineering concept has existed since the beginnings of human history and can be located at the moment when our ancestors developed the essential survival tools such as hammers, levers, pulleys, wheels, wedges, etc. UNESCO (2010; pp. 23). They proposed a wide definition for engineering as the field, discipline, practice, profession and art related with the development, acquisition and application of the technical, scientific and mathematical knowledge regarding the understanding, design development, invention, innovation and use of materials, machines, structures, systems and processes for specific purposes.

Engineering has always played a central role as intermediary among science, technology, society and natures. In fact, engineers use scientific knowledge and the tools developed by the previous techniques and technologies in conjunction with mathematics to create new technology and infrastructure to respond to the society needs and problems. Furthermore, engineers connect the society needs with the economy through commercial applications and innovations.

We shall also note that there exists an important relation between the practice of engineering and science. Pinelli (2014) defines that the fundamental difference between engineers and scientists is situated in the results of their work since scientists produce explicit knowledge, while engineers produce designs, products, processes and artefacts with direct social benefit.

\section{From Science to Macroscience}

Schummer (2012) points out that along the XVII century and in some countries even during the XVIII century, nature study was divided in three main branches: (1) natural history (historia naturalis) or the study of the animals, vegetables and mineral kingdoms as well as geography by systematic observation; (2) natural philosophy (philosophya naturalis) whose original meaning was the studies of the causes and principles of the bodies and the natural phenomena, including the material elements and what we now know as chemistry; and (3) the applied mathematics or mixed mathematics (mathemática mixta) or the measurement and quantification or geometric description of the natural phenomena, including astronomy, optics and rational mechanics.

For his part, Echeverría (2003) says that since the XV century and up to the XVIII century, in Europe was developed what he calls, small science, referring specifically to classic mechanics, thermodynamics and fluids physics without considering the emerging chemistry, biology and the social sciences. At the end of XVIII century appeared the Dalton's atomic theory, giving birth to the chemical species concept. (Gribbin, 2006)

Later, toward the end of the XIX century and early XX century, to the classic mechanics studies were aggregated other studies like quantum mechanics, relativity and statistics giving rise to the movement known as modern science. From that epoch are notable the works of Rashevsky (1938/48) about mathematic biology (biophysics). 
After the Second World War, during Paper Clip Operation in the United States of America appeared the big science. The essential difference in regards to the small science was that its efforts focused in the generation of new knowledge and the use of it to solve society needs. Echeverría (2010-2) points out that big science, also known as macro-science is the first phase of the techno-science that appeared at the end of the XX century's 40's decade, characterized because the great national interest research programs were mainly financed by the USA Federal Government. Later there were created specific Federal Agencies as the National Science Foundation (NSF), The Atomic Energy Commission (AEC), The National Aerospace Agency (NASA), the National Institutes of Health (NIH) and the Brookhaven Laboratory among others. (Brooks, 1994).

The distinctive feature of the first phase of techno-science was the axis projects defined from a social contract that included the development country strategy. The development of these projects required the concurrence of multiple agents like scientists, technologists, technicians, engineers, economists, administrators, lawyers, politics and support personnel. Two particularly important aspects about the development teams of techno-science's first phase were the inclusion of high level direction and the technological management of R\&D projects.

Many projects were carried out by private industries associated with Government Agencies linked to important organizations like the Berkeley Radiation Laboratories, the Massachusetts Institute of Technology, the Klystron Labs and the University of Pennsylvania, among others.

Some relevant projects of the big science, that transformed the world were the Manhattan project that produced the atomic bomb, the development of the radar and satellite telecommunication systems and the development of the totally digital ENIAC computer conceived as a differential calculus machine that used the innovator concept of programs resident in memory, and the execution of its process and operations via machine language instructions

The development of techno-science projects continued during the 60's decade with the development of the spatial program and the intercontinental missiles. Recent examples are the Hubble spatial telescope, the nuclear magnetic resonance (NMR) diagnostics equipment and the human genome.

A common aspect of those projects was the integration of basic research at universities and the participation of industrial firms collaborating with specialized research centres.

The directors of the participating industries provided important elements for the macrosscience project management system, as the use of the concept of budget, emphasizing that for successful development projects it is needed to previously estimate the quantity of economic, human and material resources required, plan the expenditure and clearly define the source of the funds. For the management of $\mathrm{R} \& \mathrm{D}+\mathrm{i}$ projects, the resources control systems were adopted, the communication and information interchange system and the normative system among others. The first question to respond previous to a project execution is: Where will the money come from? (Robinson, 1994).

\section{The social contract}

The basis for the development of the techno-science projects within the period of the big science were established by Vannevar Bush who was Vice president of the Carnegie Institute in 1939. Later, in 1941 he was named director of the Office of Scientific Research and Development of the United States of America by President Roosevelt. Besides being political, 
Bush was a real techno-scientist because he as an engineer and PhD from MIT and Harvard fostered the differential analyser, direct precursor of the ENIAC computer, also of Memex, antecedent of the World Wide Web and of the atomic bomb. In 1945 during the early days of the post-war era, he presented the report "Science the Endless Frontier" in which he established the bases of the Science and Technology System of the USA, highlighting that it must be conceived as a strategic factor for the country.

Is important to note that this report clearly pointed out that techno-science projects must have intense interaction between science and technology in the development of large strategic projects and the participation of the industrial firms. It also established that for the macroscience projects development, work teams formed by governmental agencies and industrial firms, coordinated by project directors and with the participation of multiple experts not just in science and technology but in economy, administration, political and social science also lawyers, among others were required.

By 1949, Truman, then president of the USA was convinced of the Science and Technology System and talking optimistically about the immense benefits that the technical assistance could bring to solve the desperate situation of the poor people of the world, said: "We must embark on a bold new program to make the benefits of our scientific advances and industrial progress available for the improvement and growth of underdeveloped areas". (Rosenberg, 1970, pp 71).

Essentially, the Bush report proposed that the effective way used for developing large projects during the war periods should be used for the projects developed during peace times and use this potential for the country's growth.

Within this framework the scientific activity increased and circa in 1960 there was an academic explosion generating an immense quantity of works and scientific articles making the study of different measurement techniques of the size of science, or Scientometrics (De Solla Price, 1965) necessary. In his book "Little science - Big Science", Derek Solla Price found that scientific publications had an exponential growth during the Second World War. This phenomenon meant that more than $80 \%$ of the scientific knowledge of the world was produced since early XX century within the big science era well into our days, while the whole scientific knowledge that was produced in the world during all the previous centuries was just about 20\%. (Solla Price, 1963). Today it is estimated that global information and knowledge are duplicated every five years. (Brunner, 1998).

\section{Techno-science emergence and consolidation}

The techno-sciences term seems to be relatively new because it was suggested by the Belgian philosopher G. Hottois (1984) and later generalized by the French philosopher B. Latour (1987), but it is really re-emerging because it existed since Bacon's times. For Klein (2005), techno-science is composed by interconnected systems of science and technology which existed long before the nineteenth century. A clear example is the carbon chemistry of the years 1820 to 1840 that originated the synthetic dyes industry. The current techno-science emigrated from the US to other developed countries like England, France and Canada before moving on to other countries.

According to Martínez (2013, pp. 107), for Echeverría, the relevant aspect of the technoscience is that it modifies the social world and not just the nature, the important thing is the transformation of the world that takes place, because the modern form of work requires the joint work of engineers and scientists for the development of joint projects, provoking the 
natural knowledge circulation or the knowledge socialization between them. In that regard, the political, administrative and organizational issues acquire a special relevance. Therefore the planning, organization and execution of research and development (R\&D) are actions closely linked to the techno-science modern system.

Echeverría (2003) points out that the techno-science system is a different way to carry out research and development (R\&D) in respect to the traditional forms. He also clarifies that is necessary to review the philosophy to avoid the confusion that exists regarding the term.

Rosenberg (2010, Op. Cit.) indicates that the adoption of the techno-science system by the firms and the American universities occurred slowly in a process that required organizational changes and economic incentives; however, it seem that the main process catalyser was the science crisis that occurred from 1965 to 1975.

The trigger for the crisis was the awareness of the social aspects in the context of the antinuclear movements, the opposition to the Vietnam War, the ecological crisis, the student demonstrations and the academic critics questioning the rational science supremacy over the technology or the neutrality of them. That's how programs of Science-Technology and Society (STS) emerged in many important American Universities. (Medina, S/D). These transdisciplinary studies are directly related with the four contexts of the scientific practice: education, research, application and evaluation. (Echeverría, 2010-1).

In summary, the crisis of the 60's decade transformed the macro-science way to develop R\&D projects into the consolidated techno-science system of the USA during the 80's. The main change was that the private financing of R\&D projects exceeded public funding, establishing the primacy of the private sector over the public sector to the extent that they could even make investments in science and technology in the Stock Exchange. Other important changes are related to the techno-science system objectives which were: to carry out the planning, implementation, coordination and evaluation activities in science and technology produced by the public and / or private organizations to make projects of national interest. Therefore it has to do with the culture of organizational work.

The original Bush proposal considered that the State must manage the techno-science activities because their results should come in their own benefit. Later both the State and the industry contributed resources for the implementation of techno-scientific projects. Finally the industry became the predominant actor.

Figure 1 shows a brief chronological summary of the evolution of science and engineering and the emergence of the techno-scientific culture including their basic features.

Today the techno-sciences are closely related to the innovation philosophy which, according to Iglesias (2006), has its foundation in the theory of action or axiology, with three main components: scientific research, technological development and innovation. (Echeverría, 2010, op. cit. pp. 33). From the above, Echeverria raises and supports the hypothesis that there has been a new scientific and technological revolution whose background was the Scientific Revolution and the Industrial Revolution in the twentieth century.

\section{The techno-scientific projects}

We can see in figure 2, we suggest the Social Universal System is divided in the subsystem of knowledge generation and the subsystem of society and nature. The model suggests that the relationship between society and the system of generating knowledge occurs through different 
actors who develop techno-scientific projects to respond to the needs of society with resources coming from the same, delivering products and benefits to be used by the same society.

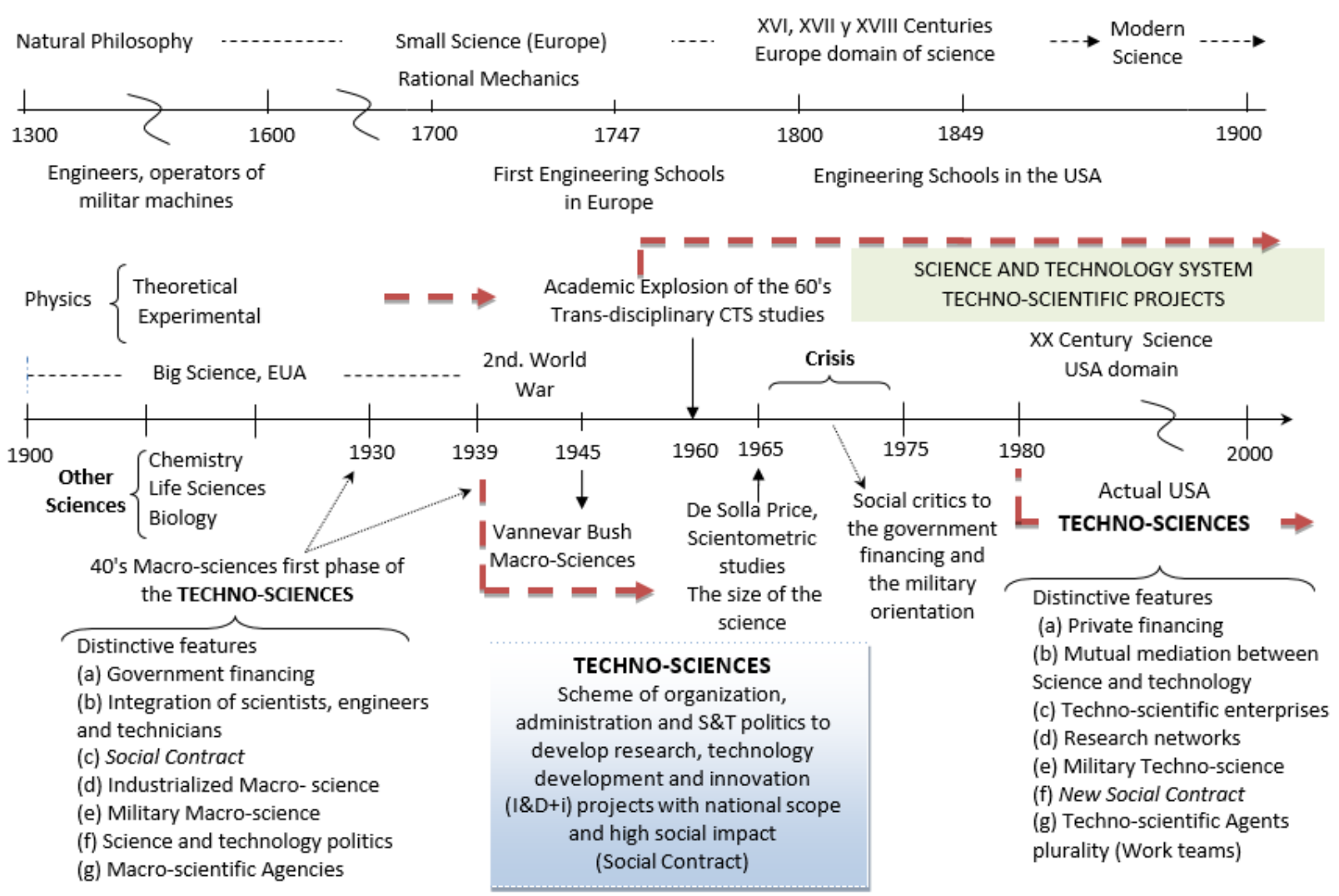

Figure 1. Historical records and evolution of the techno-sciences characteristics

In the same figure we show that a techno-scientific organization is capable of developing techno-scientific projects and it is composed of many different actors as the scientists, technicians, engineers, administrators, economists, lawyers and support personnel, who work following politics and laws of $\mathrm{R} \& \mathrm{D}+\mathrm{i}$ determined by the federal government in terms of the strategic definitions contained in the social contract of the country's science and technology system.

The hearth of the model is the working team formed by scientists, engineers and technicians and many other professionals responsible for developing techno-scientific projects.

The scientists provide theories; the technologists contribute with tools and the technicians with mathematics and diverse manual techniques. All this knowledge and skills allow engineers to comprehend, design, develop, invent and innovate through solutions or technological products responding to the needs of the productive system or social utility.

In the figure we can see that the techno-scientific organization which is responsible for the achievement of a techno-scientific project requires the establishment of a network that receives $R \& D$ contributions from other universities or techno-scientific organizations, and vice versa, these organizations could give support to the R\&D performed by the universities and the industries. (Mansfield, Lee; 1996).

The primary focus of the techno-scientific projects is the change and improvement of society; therefore, sometimes the result of these kind of projects are disruptive innovations known as Catalytic Innovations (Christensen, et. al., 2006). 


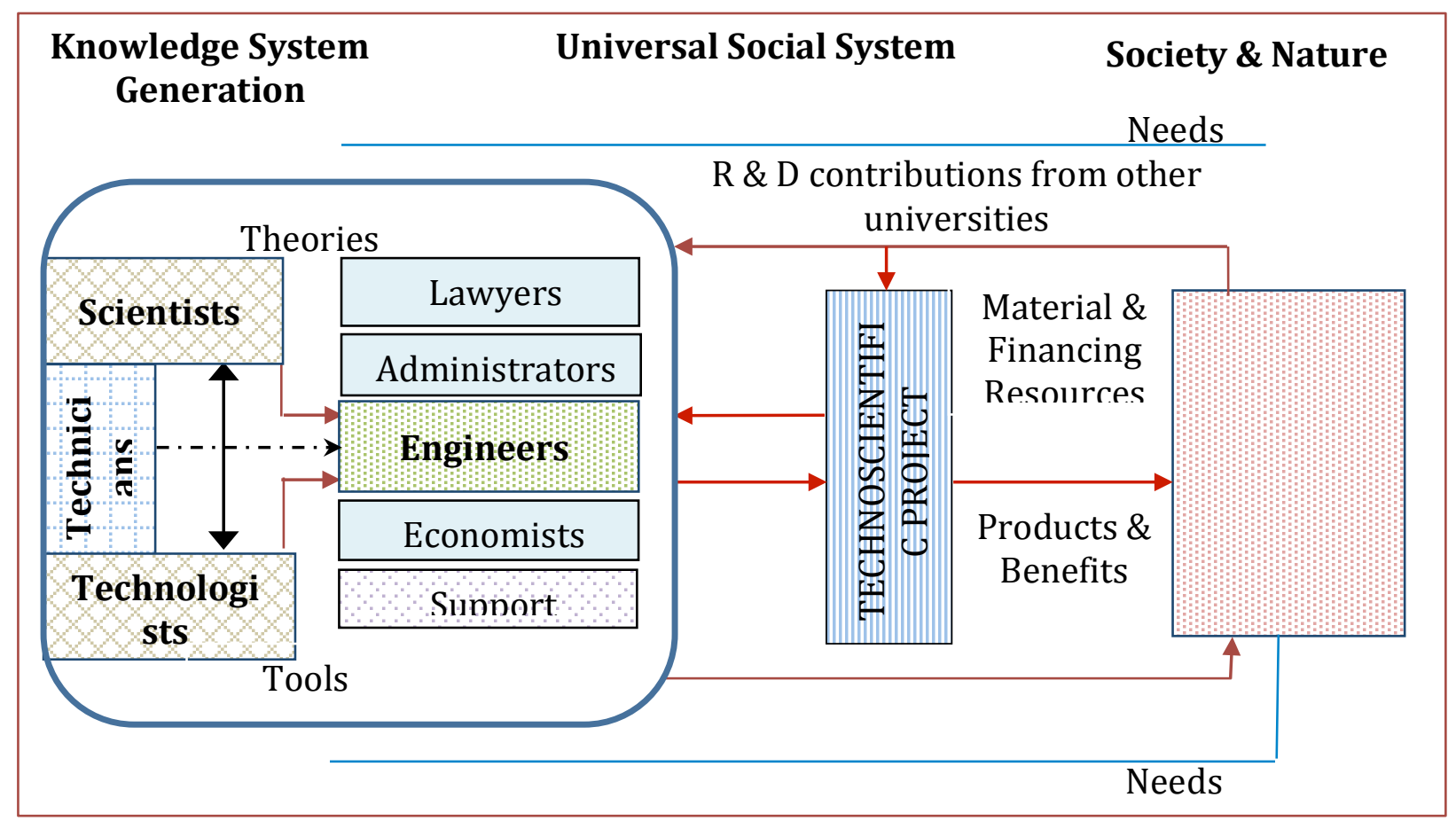

Figure 2 Organization \& technoscientific projects.

Another result derived is the establishment of good practices, administration and project management through the promotion and linking between universities and other organizations that perform engineering, such as public or private firms and industries to assist the modernization of low and medium technology firms. (Etzkowitz et. al., 2000).

Latour (1987), cited by Pinelli (Op. Cit., page 10), found that successful techno-scientific projects depend not only on how well scientists do their work together with the engineers, but if they are willing to network with others to submit proposals seeking project finance, negotiations, etc.

Engineers and scientists of all specialties work in techno-scientific organizations. A case worthy of special mention is Chemistry, as this discipline can be seen as a science or as an engineering as well. Analysing Chemistry as a basic science is very productive from the Scientometric point of view. Chamizo (2013) mentions that the growth of the Chemistry information was impressive during the last century. On the other hand, chemistry is an experimental science based on laboratory facts, which makes use of instruments and apparatus to increase certainty and experimental performance. Therefore, Chemistry can be seen as a modern science, which stems from the experiential and sensory perception, where the quantifiable and verifiable are taken as sole criteria of truth and rationality. (Piñon, 2007).

In other words, all that matters is what can be measured. This approach has been recognized as the Instrumental Chemical Revolution. Chamizo (2011) cites the proposal of Laudan (1997) that science is essentially a problem solving activity, which is also an engineering activity, with the difference that engineers are generally in charge of the "world design".

\section{Axiology of the techno-scientific projects}

The techno-scientific system not only has to do with how to generate knowledge and skills but how to act as well; that is, in the techno-scientific system the philosophy of action or axiology prevails. (Chamizo, 2013; Op. Cit., pp. 158). This system focuses on the need for utilitarian technology beyond the pure and disinterested science. 
For Bensaude-Vincent et al., (2010), the techno-science is a neutral term used to describe the actual situation of the scientific research, because it establishes the goals that guide and direct the investigation and that allows the observation of the different activities or practical ways even within the investigation field itself.

So, we can understand the techno-sciences system as a bridge between thought and usefulness through the action mediated by techno-scientific work teams. This model is consistent with the rational action as Bunge (2004, p 24), which is required as scientific knowledge comes to practice. As we can see in figure 3, the techno-science system is not only made up of a system of organizational policies for the implementation of R\&D+i projects, but from an axiological point of view, it can have the following three great action areas: (a) the hybridization of science and technology, (b) the politics and organization for the R\&D+I, and (c) the execution of R\&D+I projects.

Hybridization of Science and technology. This area of the techno-sciences is located next to the knowledge generation system, and it is characterized by the integration of scientists, engineers, technicians with the ultimate goal of producing knowledge and innovative devices for the benefit of man, its institutions and to promote social and economic progress. It should be noted that one of the satisfiers of society developed by engineers are the apparatus, instruments and tools for the development of R\&D+i.

The importance of the development of scientific instruments has been highlighted by Rosenberg (1997), who notes that they are capital goods for industry research. This is very important because the innovation process stems from the development of capital goods or general purpose technologies that drive economic development through the development of complementary innovations or improvements to disruptive technologies. (Rosenberg, 2010, op. Cit., P.67).

Politics and organization for R\&D+i. The first policies established by Vannevar Bush in the report Science the Endless Frontier, laid the foundations of the science and technology of USA from the 40's to 60's of last century. They stated that the requirement to carry out large research, technological development and innovation (R\&D+i) projects, was the formation of networks with the participation of the government as coordinator and financier, and universities and other organizations that perform R\&D within society. It should be noted that industries and companies had an important role in establishing laboratories of industrial R \& D (Industrial Lab). Since last century's 80's until today, in developed countries both scientific and technological projects coexist with their traditional targets such as techno-scientific projects. 


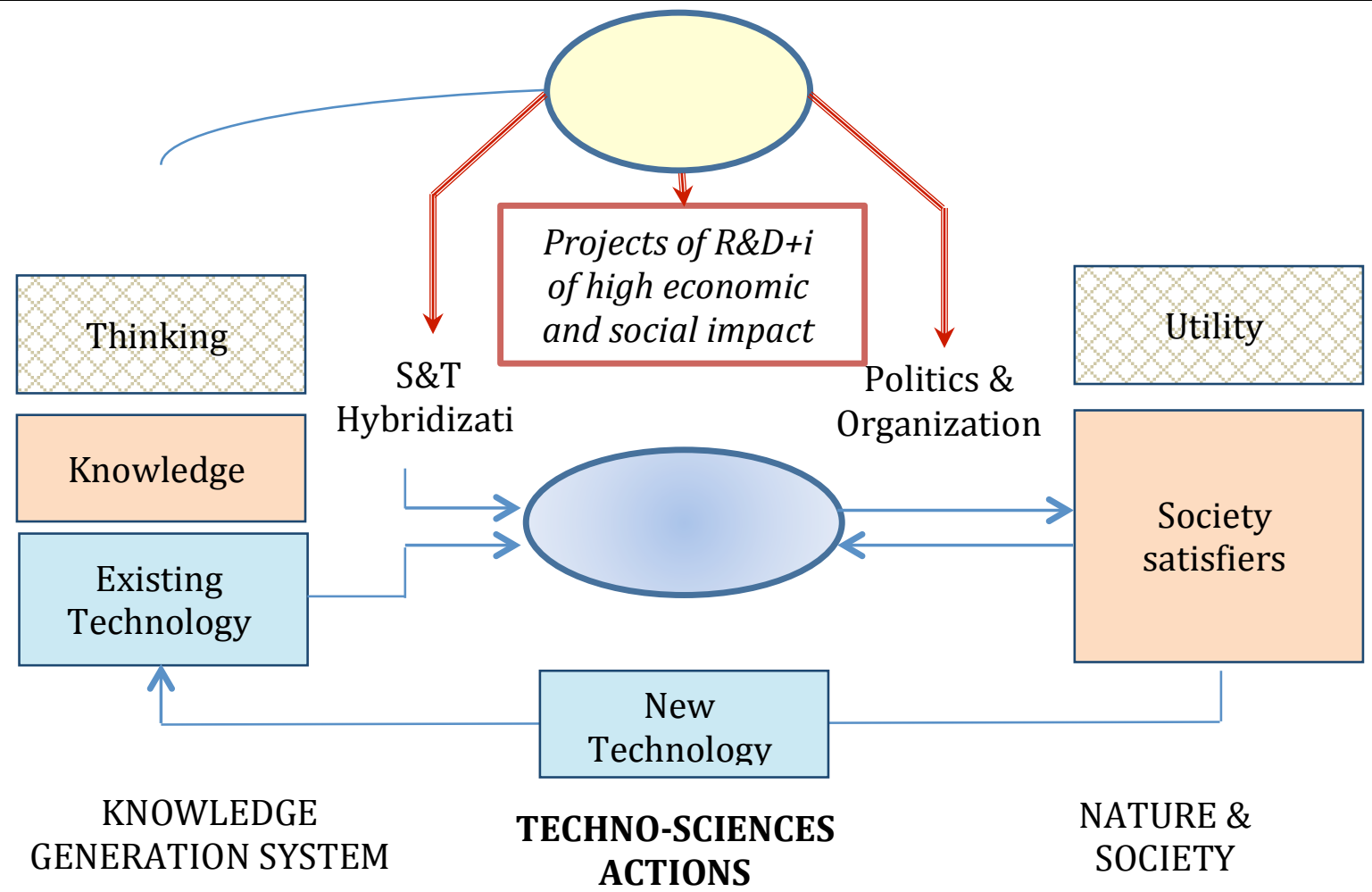

Figure 3. The techno-science as the thinking-action-utility bridge

The modern Science and Technology System establish that the object of harmonious and respectful common work of interdisciplinary teams of scientists, basic technicians, engineers, and other stakeholders is the strategic project. Iglesias (2006; Op. Cit. page 127).

The definition of this type of project requires strategic and technological planning; furthermore, they should be formulated on the basis of R\&D+i policies established in the social contract which must have a clearly stated intention and must be fully accepted by members of society. Techno-scientific actions should be guided by values, they are never spontaneous, "there are always reasons to make and achieve goals with them." (Echeverria, 2008).

The values should not only be related to the economic benefit to be gained from the result of projects, but with aspects such as national identity and growth, leadership, social welfare, prestige, control, domination, submission, and so on.

\section{Techno-scientific projects in México}

In México the Science and Technology politics are established by the Federal Government in the Scientific and Technologic National Plan coordinated by the National Council of Science and Technology (CONACYT, for its acronym in Spanish), (CONACYT, 2014).

The last governmental effort developed through CONACYT, in regard to science and technology is the Programa Especial de Ciencia, Tecnología e Innovación 2014-2018 which structural framework states "There is the belief that investment in science and technology is a key to access a welfare economy, knowledge-based tool, in this knowledge economy". (PECETI, 2014).

In this special program the actors suggested for the National System of Science Technology and Innovation are: the government, enterprises, and institutions of superior education, the nonlucrative private sector and some organizations from the exterior. Noticeably the PECETI's presentation document states: "the articulation work results difficult" 
In the PECETI the categories of the federal government expenditures are: (a) scholarships for postgraduate students, Masters and PhD's, (b) postgraduate institutional programs, (c) basic science projects, (d) economic stimuli in the national system of researchers and (e) projects stimuli for innovation.

CONACYT actually promotes and finances $R \& D+i$ projects through different funds: Sectorial Covering all the economy sectors, together with the government of Mexican States, Institutional and the Program of Incentives for Innovation (PEI). The objective of the PEI program is to encourage and promote the growth and competitiveness of enterprises.

Possibly the Funds financing is the closest scheme to the techno-sciences system in the country.

Through these programs in basis to a yearly convocation, CONACYT sponsors innovation projects for enterprises and organizations in public and private sectors within Mexican society. To grant sponsorship it is required as a condition that the requesting organization establishes and shows linking with universities and public/private research institutions.

\section{Based in the PECETI, CONACYT actually promotes R\&D+i projects through the different Funds} shown in Table 1:

Table I. CONACYT's Mexican Funds. (CONACYT, 2015)

\begin{tabular}{|c|c|c|c|}
\hline Name of the Fund & $\begin{array}{c}\text { Number of } \\
\text { different Funds }\end{array}$ & $\begin{array}{lr}\text { Bank } & \text { Balance } \\
\text { Mexican } & \text { Million } \\
\text { Pesos } & \end{array}$ & \\
\hline Institutional & 4 & $\$ 5,352$ & \\
\hline Mix & 25 & $\$ 3,545$ & $\begin{array}{l}\text { With participation } \\
\text { of the State } \\
\text { government of the } \\
\text { Mexican Republic }\end{array}$ \\
\hline Sectorial & 23 & $\$ 17,475$ & \\
\hline $\begin{array}{l}\text { Fondo de } \\
\text { Investigación y } \\
\text { Desarrollo para la } \\
\text { modernización } \\
\text { tecnológica } \\
\text { (Fidetec) } \\
\end{array}$ & 1 & $\$ 3$ & $\begin{array}{l}\text { Spin Off and } \\
\text { incubators }\end{array}$ \\
\hline \multicolumn{2}{|r|}{ Total } & $\$ 26,375$ & \\
\hline
\end{tabular}

It is noteworthy that although the PECETI mentioned that companies are key players in the Mexican system of science and technology, large enterprises are absent because just a few big enterprises have developed their own industrial research laboratories whose researchers, engineers and technologists can communicate fully with investigators and academics from universities for the development and achievement of projects. Unfortunately large companies constitute only about $1.5 \%$ of the Mexican business structure. (Diario Oficial, 2008). Therefore, there is a long way in order for the model to be adopted in full by the industrial sector.

On the other hand, in Chapter III of the 2015 Mexican Federal Law of Science and Technology, there are some comments such as: "These politics should be periodically reviewed and updated, an ongoing effort under assessment results and trends of scientific and technological progress, and on its impact on productivity, competitiveness and the solution of the needs of the country" (Article 12, Chapter III, Nr. VIII); "The selection of institutions, programs, projects 
and people recipients of support, will be made through competitive, efficient, fair and public proceedings, supported on merit and quality, and oriented with a clear sense of social responsibility" (Article 12, Chapter III, Nr. IX); " The activity of research, technological development and innovation are preferably made directed at the solution of problems and challenges in the public interest, contributing significantly to advancing the frontiers of knowledge, improve competitiveness and productivity of economic sectors, and an increase quality of life of the population and the environment" (Article 12, Chapter III, Nr. XIII).

We can see that even there are some superficial mentions about the social responsibility, the increase on the quality of life of the population and the solution of the problems of the country, there is not an explicit social contract with firm high economic and social impact intentions; furthermore, in practice there is not a governmental definition of strategic projects and just a few Mexican firms and organizations participate in innovation projects in which, in addition to knowing the technical aspects they are required to apply technology management to develop them successfully. In addition, the entrepreneur is sporadically engaged in the design and development of institutional and government policies.

Besides, the legislative framework is insufficient; in 1991 the new Law of Intellectual Property Rights was approved to adapt it to international standards and conventions and the Law of Promotion and Protection of Intellectual Property. (Casas \& Luna, 1997, pp. 105). Finally in 1992, the Law on Standardization and Metrology came into effect seeking support on tasks aimed to improve the quality and improvement of products and, consequently, the competitiveness of enterprises.

\section{CONCLUSIONS}

The science-technology-society relationship is common in all modern industrial societies. Science and technology become interdependent and benefit one from the other in order to offer goods, products and services required by society generating economic and social progress. Therefore in the work teams of the techno-scientific organizations the stakeholders must respect each other. Also, their contributions in the $R \& D+i$ projects in which they participate must be considered of equal importance.

The role of the techno-scientific firms and industries participating is essential because they must carry out the design, funding and administration management of the projects, establishing networks and linkages with different government agencies, universities and institutions of higher education. However, because the Mexican Law on Science and Technology just mentions that: "We will seek the concurrence of contributions from public and private national and international resources for the generation, execution and diffusion of scientific research projects, technological development and innovation" (Article 12, Chapter III, $\mathrm{Nr}$. VI), in the best case scenario, the actual contributions of the companies are about $25 \%$ of the funds for the Programa de Estímulos a la Innovación (PEI), which in the year 2015 were approximately 1,400 million pesos.

On the other hand, according to the Law of Intellectual Property, the techno-scientific firms that generate $R \& D+i$ projects will have rights for the diffusion, intellectual protection, sales and exploitation of the obtained knowledge. Similarly, all participants in the development of projects should receive fair compensation based on their contribution to the project; nevertheless, their main motivation should be the participation in projects in which results directly benefit the society they belong to. 
The role of the technicians is relevant because manual techniques are the fundament for technology development and the Technicians are those who "do" things physically, carrying out the production of designs, testing, modifying them and keeping them; Thus, their participation in techno-scientific projects must also be valued and widely recognized.

According with recent results on the measurement of poverty in México (CONEVAL, 2010), 52 million Mexicans from a total of 115 million, are living in poverty, and out of these, 11.7 million in extreme poverty. In addition to poverty rates, those concerning marginalization, unemployment, crime, population explosion, so on, show that the techno-sciences are not fully established in the country.

Moreover, the scope of the projects R \& D performed in Mexico is very limited, so no one can say that they are techno-scientific projects. Its objectives are limited to the specific application or demand for any industry or service company.

The average financing for the CONACYT's PEI program is between 3 to 5 million pesos or less, with maximum of about 30 to 40 million pesos, quantities comparable to the cost of $\$ 500,000.00$ USD required for the development of the ENIAC computer in 1950 . This quantity represents today $\$ 2,000,000.00$ USD, at an interest yearly rate of $2 \%$.

In spite of this, the problem is that the projects that obtain this financing amount just respond to the modernization or innovation purposes of a sole firm. Perhaps none of the projects that obtain this amount of financing respond to major national problems that are of wide economic and social scope.

While recognizing that through the PECETI program significant efforts are made, we still have important organizational problems. For instance, one of the major problems is the formation of techno-scientific work teams where scientists, technologists, engineers, technicians and other professionals should coexist and fully respect the work of others.

We believe that CONACYT's Science and Technology for innovation projects is still a very bureaucratic process, therefore the project teams continue doing the work that have been taking place for centuries, they must hold the Mexican productive plant operation, assimilate, adapt and develop technology, conduct research and develop human resources; among others.

We think that just as it happened in developed countries, the first step should be taken by the actors of science and technology and innovation system established in the PECETI and coordinated by the federal government, possibly through CONACYT.

They must work on the development of a social contract adapted to the Mexican environment in which industry and producer organizations should actively participate in order for the techno-sciences system to be fully established in the country.

A good start for teams to be able to develop innovation projects that will later become technoscientific projects, would be to learn to work together recognizing and valuing the work and contribution of each of the members to successfully reach the goal set in the project.

In short, nowadays in Mexico not large techno-scientific projects with high economic and social impact are developed, hitherto only projects of research, development and innovation of limited scope and objectives are achieved 


\section{References}

Bensaude-Vincent, B., Loeve, S., Nordman, A., Schwartz, A., (2011). Matters of Interest: The Objects of Research in Science and Technoscience. J Gen Philos Science. Vol. 42, pp. 365-383. DOI 10.1007/s10838-011-9172-y

Brooks, H., (1994). Understanding the Bush Report. Science the Endless Frontier 1945-1995: learning from the past, designing for the future. Conference Highlights. Consulted in:

http://archive.cspo.org/products/conferences/bush/fulltexthighlights.pdf, page 13.

Brunner, J. J., (1998). Globalización Cultural y Posmodernidad. Breviarios Fondo de Cultura Económica, Chile, S.A., Santiago.

Bunge, M., (2004). La investigación científica: su estrategia y su filosofía. Siglo XXI, Eds. 3aa ed., 809 p.

Casas, R., Luna M., (Coord.) (1997). Gobierno, academia y empresas en México: Hacia una nueva configuración de relaciones. Plaza y Valdés, 1a Ed., pp.346.

Chandler, A. D., (1977).The Visible Hand: The Managerial Revolution in American Business. Cambridge, MA.

Belknap Press.

Chamizo, J. A., (2011). La imagen pública de la química. Educ. Quím. Vol. 22, No. 4, pp. 320-331, 2011.Universidad Nacional Autónoma de México, ISSN 0187-893-X.

Chamizo, J. A., (2013). Technochemistry: One of the chemists' ways of knowing. Found Chem. Vol.15, pp. 157-17, DOI 10.1007/s10698-013-9179-z

Christensen, C. M., Baumann, H., Ruggles, R., Sadtler, T. M., (2006).Disruptive Innovation for Social Change. Harvard Business Review. pp. 94-101.

CONACYT (2014).Programa de Estímulos a la Innovación. Disponible en http://www.conacyt.mx/index.php/fondos-y-apoyos/programa-de-estimulos-a-la-innovacion.Recuperado el 17 de noviembre de 2014.

CONACYT (2015). Información Financiera de fondos CONACYT. Recuperado de:

http://www.conacyt.gob.mx/images/pdfs_conacyt/Fondos_y_Fideicomisos/Situacion_Financiera_de_Fondos_CON ACYT.pdf

CONEVAL (2010), 'Rezago educativo, acceso a los servicios de salud, seguridad social, calidad y espacios de la vivienda, acceso a servicios básicos de vivienda y a la alimentación'.

http://internet.coneval.gob.mx/Informes/interactivo_nacional.swf

Diario Oficial de la Federación, (2008). Acuerdo por el que se establecen las Reglas de Operación para el otorgamiento de Apoyos Del Fondo de Apoyo para la Micro, Pequeña y Mediana Empresa (FONDO PyME). Decimoquinta Sección. Secretaría de Economía.

Echeverria, J., (2003). La revolución tecnocientífica. Fondo de Cultura Económica, Madrid, 282p.

Echeverría, J., (2010-1). De la filosofía de la ciencia a la filosofía de la tecnociencia. $\Delta \alpha \mathbf{l}^{\prime} \mu \omega v$. Revista Internacional de Filosofía, No. 50, pp. 31-41. ISSN: 1130-0507.

Echeverría, J., (2010-2). Tecnociencia, tecnoética y tecnoaxiología. Revista Colombiana de Bioética, Vol. 5, No. 1, pp. 142-152.ISSN: 1900-6896.

Dillon, B. S., (2008). Creativity for Engineers. Series on Systems and Industrial Engineering Vol. 3. World Scientific Publishing Co., 1st Ed., pp. 181.

Etzkowitz, H., Webster, A., Gebhardt, C., Cantisano, T. B. R., (2000). The future of the university and the University of the Future: evolution of ivory tower to entrepreneurial paradigm. Research Policy. Vol. 29, pp. 313-330.

Godin, B., Lane, J. P., (2012). A century of talks on research: what happened to development and production? Int. Journal Transitions and Innovation Systems, Vol. 2 No. 1, pp. 5-13.

Gribbin, John (2006). Historia de la ciencia, 1543-2001 (2ª edición). Barcelona: Crítica, S.L. ISBN 84-8432-607-1.

Hottois, G., (1984). Le Signe ET la technique. La philosophie an ' l'e'preuve de la technique [The sign and the technique Philosophy to the test of the technique]. Aubier, Paris. 
Iglesias, M., (2006). Reseña de "La revolución tecnocientífica" de Echeverría, Javier. Opción, vol. 22, No. 49, abril, 2006, pp. 126-130, Universidad del Zulia, Venezuela.

Instituto de Investigaciones Jurídicas UNAM (2015). Ley de Ciencia y Tecnología. Capítulo III Principios Orientadores del Apoyo a la Investigación Científica, Desarrollo Tecnológico e Innovación. Recuperado de: http://info4.juridicas.unam.mx/ijure/fed/30/14.htm?s=

Klein, U., (2005). Technoscience avant la letter. Perspectives on Science. Vol. 13, No. 2, pp. 226-266. Max Planck Institute for the History of Science.

Latour, B. (1987). Science in Action: How to Follow Scientists and Engineers through Society. Cambridge, MA. Harvard University Press.

Lucena, J. C., (2007). De Criollos a Mexicanos: Engineers'Identity and the Construction of Mexico. History and Technology. Vol. 23, No. 3, pp. 275-288.

Mansfield, E., Lee, J-Y., (1996). The modern university: contributor to industrial innovation and recipient of industrial R\&D support. Research Policy. Vol. 25, pp. 1047-1058.

Martínez, V. P. I., (2013). De la ciencia a la tecnociencia: comparación entre el esquematismo Kuhniano del cambio científico y la actividad tecnocientífica, desde el discurso de Echeverría. Tesis de Licenciado en Filosofía, Facultad de Estudios Superiores Acatlán, Universidad Nacional Autónoma de México.

Marx, L., (2010). Technology: the emergence of a hazardous concept. Technology and Culture, Vol. 51, No. 3, pp. 561-577.

Medina, M., (S/D). Ciencia, Tecnología y Sociedad en el siglo 21. Los retos de la tecnociencia y la cultura de CTS. Disponible en:

http://garritz.com/andoni_garritz_ruiz/documentos/Los\%20estudios\%20CTS/Medina_CTS_sigloXXI.pdf. Consultado 17 diciembre 2014.

Mwamila, B. L. M., Diyamett, B. D., (2009). Universities and socio-economic development in Tanzania: public perceptions and realities on the ground. Science and Policy. Vol. 36, No. 2, pp. 85-90.

Porter, T. M. (1995).Trust in Numbers: The Pursuit of Objectivity in Science and Public Life. Princeton, NJ: Princeton University Press.

Picon, A., (2004). Engineers and Engineering History: Problems and Perspectives. History and Technology. Vol. 20, No. 4, pp. 421-436.

Pinnelli, T. E., (2014).Distinguishing Engineers from Scientists-The Case for an Engineering Knowledge Community. Science \& Technology Libraries, 21:3-4, 131-163, DOI: 10.1300/J122v21n03_09

Piñón, G. F., (2000). Filosofía, Eticidad y Tecnociencia: los conflictos de la modernidad. En Ética y política: entre tradición y modernidad, Francisco Piñón Gaytán y Joel Flores Rentería (coords.), Ed. Plaza y Valdés/Centro Gramsci UAM, México; pp. 71-81.

Rashevsky, N., (1938/48). Mathematical Biophysics: Physico-Mathematical Foundations of Biology. University of Chicago Press. 2nd Ed.

Robinson, D., (1994). Show me the Money: Budgeting in a Complex R\&D System. Science the Endless Frontier 1945-1995: learning from the past, designing for the future. Conference Highlights. Consulted in: http://archive.cspo.org/products/conferences/bush/fulltexthighlights.pdf; page 46.

Rosenberg, N., (1979). Economic Development and the Transfer of Technology: Some Historical Perspectives. Technology and Culture, Vol. 11 No. 4; pp. 550-575.

Rosenberg, N., (1997). The economic impact of Scientific Instrumentation Developed in Academic Laboratories., in Equipping Science for the 21st Century. John Irvine (Ed), pp. 43-55.

Rosenberg, N., (2010). Endogenous forces in 20th Century America. Entrepreneurship, Innovation and the Growth Mechanism of the Free Enterprise Economies, In: Studies in Science and the Innovation process, Selected Works by Nathan Rosenberg. World Scientific Publishing Co. Ltd.

Schatzberg, E., (2006). Technik comes to America: Changing meanings of technology before 1930. Technology and Culture, Volume 47, Number 3, pp. 486-512. 
Schummer, J., (2012). Why Mathematical Chemistry cannot copy Mathematical Physics and how to avoid the imminent epistemological pitfalls. International Journal for Philosophy of Chemistry, Vol. 18, pp.71-89.

Solla Price D. J., (1963). Little science, big science. New York: Columbia University Press, 1963. 119 pp. Yale University, New Haven, CT.

Solla Price, D. J., (1965). Networks of scientific papers. Science, Vol. 149(3683), pp. 510-515.

UNESCO, (2010). Report Engineering: Issues Challenges and Opportunities for Development. UNESCO Publishing, France; pp.396.

Veblen, T., (1906).The Place of Science in Modern Civilization. American Journal of Sociology.Vol. 11 pp. $585-609$.

Vérin, H., (1982). Entrepreneurs, Entreprises: Histoire d'une Idée. Paris: PUF, 1982

Wiesner, J. B., (1979). Vannevar Bush (1890-1974). Biographical Memoir. National Academy of Sciences, Washington, D.C. 